\title{
The "New" Problem of Humanity: New Coronavirus (2019-nCoV / COVID-19) Disease
}

\author{
Insanlığın "Yeni" Sorunu: Yeni Koronavirüs (2019-nCoV / COVID-19) Hastalığı \\ Nevin Hatipoğlu $\odot$
}

SBÜ Bakırköy Dr Sadi Konuk SUAM, Clinics of Children's Health and Diseases, Istanbul, Turkey

Received: 06 March 2020 / Accepted: 11 March 2020 / Publication date: 26 March 2020

Cite as: Hatipoğlu N. The "new" problem of humanity: New coronavirus (2019-nCoV / COVID-19) disease. Med J Bakirkoy 2020;16(1):1-8.

\begin{abstract}
At the end of December 2019, a new respiratory virus infection was identified in Wuhan city, China, in the province of Hubei, after patients with acute severe respiratory infections showed clustering. The cases were thought that they could be related to exposure in the Huanan Seafood Market where wholesale fish and live animals are sold in this city. In January 2019, the causative agent was named 2019-nCoV (2019 novel coronavirus), severe acute respiratory syndrome coronavirus 2 (SARS-CoV-2) and 2019 coronavirus disease (COVID-19) by the World Health Organization (WHO).

Coronaviruses are enveloped and single-stranded RNA viruses of the Coronaviridae family and are known as "crown viruses" due to their crown-like protrusions on their outer surfaces. They can infect various species. In addition to mild upper respiratory diseases, it is the causative agent of serious acute respiratory syndrome (SARS) and Middle East respiratory syndrome (MERS). 2019-nCoV shows 79\% similarity to SARS-CoV and means that bats such as SARS-CoV may have been the original host of this virus. The route of transmission is by respiratory droplets and direct contact. In order to prevent the spread of infection, early diagnosis, proper isolation and personal protective measures are especially important in the hospital environment. The agent uses angiotensin converting enzyme 2 (ACE2) receptor to enter the cell. The incubation period is usually 3-7 days and can extend up to 14 days. While it is more severe in upper-middle aged people, those with advanced age and additional comorbidities pose risk factors for severe disease. Adult patients have high fever, weakness and dry cough, and some have headaches and muscle pain. As the disease period progresses, shortness of breath acute respiratory distress syndrome, septic shock, metabolic acidosis, clotting disorders, and multiple organ failure may occur. In particular, children can pose an unnoticed threat in spreading the outbreak. Children are less likely than adults to have the infection as an obvious clinical status. The clinical features of the disease are milder and death has not been reported under 10 years of age. Blood count and C-reactive protein values can usually be found normal or slightly increased. In the radiological evaluation of the lung, ground glass appearance and bronchial shadows may be evident. A nucleic acid test is performed from the nose or throat swab to determine the exact cause of the disease. Adequate calorie and fluid intake and the need for oxygen should be ensured in the treatment. An effective anti-virus treatment is not yet available. However, in severe cases, interferon- $\alpha$ nebulization and efficacy have not been proven, lopinavir / ritonavir and chloroquine are recommended. In certain cases, corticosteroids can be used. The virus can be inactivated with disinfectants containing ethanol and chlorine. People with close contacts and suspicious exposure should be advised of 14 days of observation and isolation, starting from the last contact day with the patient infected with 2019-nCoV. Vaccine development studies for 2019-nCoV are ongoing.
\end{abstract}

Keywords: 2019-nCoV, SARS-CoV-2, COVID-19, severe acute respiratory syndrome

öz

Ilk olarak 2019 Aralık ayı sonunda Çin'in Hubei eyaletinde bulunan Wuhan kentinde akut ağır solunum yolu enfeksiyonu tanılı hastaların kümelenme göstermesi üzerine dikkat çeken yeni bir solunum virüs enfeksiyonu tanımlandı ve vakaların bu şehirde bulunan toptan balık ve canlı hayvan satışının yapıldığı Huanan Deniz Ürünleri Pazarı́nda maruziyetle ilișkili olabileceğini bildirdi. Ocak 2019 içinde de etken Dünya Sağılk Örgütü (DSÖ) tarafından 2019-nCoV (2019 novel coronavirus), siddetli akut solunum sendromu koronavirüs 2 (SARS-CoV-2) ve 2019 koronavirüs hastalı̆̆ı (COVID-19) virüsü olarak adlandırıldı.

Koronavirüsler Coronaviridae ailesinin zarflı ve tek sarmallı RNA virüsleridir ve dış yüzeylerindeki taç benzeri çııntılarından dolayı "taç virüs" olarak bilinir. Çeşitli canlı türünü enfekte edebilirler. Hafif üst solunum yolu hastalıkları yanında ciddi akut solunum sendromu (SARS) ve Orta Doğu solunum sendromu (MERS) etkenidir. 2019nCoV SARS-CoV'a \%79 benzerlik göstermektedir ve SARS-CoV gibi yarasaların bu virüsün orijinal konağı olabileceği anlamına gelmektedir. Bulașma yolu solunum damlacıklarıyla ve doğrudan temasla olmaktadır. Enfeksiyonun yayılmasını engellemek için erken tanısı, uygun izolasyon ve özellikle hastane ortamında kişisel koruyucu önlemler çok önemlidir. Etken hücre içine girmek için anjiotensin dönüştürücü enzim 2 (ACE2) reseptörünü kullanmaktadır. Kuluçka süresi genellikle 3-7 gündür ve 14 güne kadar uzayabilir. Daha çok orta yas üzeri kissilerde daha ağır klinik tablo oluștururken yoğun bakıma yatııllanlar ileri yașta ve ek hastalığı bulunanlar olmaktadır. Eriškinlerde yüksek ates, halsizlik ve kuru öksürük, bazılarında bas ağrısı ve kas ağrısı görülür. ilerledikçe nefes darlığı akut solunum sıkıntısı sendromu, septik şok, metabolik asidoz, pıhtılaşma bozuklukları ve çoklu organ yetmezliği oluşabilir. Özellikle çocuklar, salgını yaymada farkedilmeyen tehdidi oluşturabilir. Çocuklarda enfeksiyonun aşikar hastalık olarak ortaya çıkma ihtimali erişkinlerden daha azdır; hastalığın klinik özellikleri daha hafiftir ve ölüm 10 yas altına bildirilmemiștir. Kan sayımı ve C-reaktif protein değerleri genellikle normal ya da hafif artmış bulunabilir. Akciğer radyolojik değerlendirmesinde buzlu cam görünümü ve bronşiyal izlerde belirginleşme olabilir. Hastalığın etkeninin kesin ortaya konması için burun veya boğaz sürüntüsünden nükleik asit testi yapılır.

Tedavide yeterli kalori ve sıvı alımının sağlanmalı, oksijen ihtiyacı giderilmelidir. Etkili bir virüs karşıtı tedavisi henüz mevcut değildir; ancak ağır vakalarda interferon- $\alpha$ nebulizasyonu ve etkinliği kanıtlanmıs olmasa da lopinavir/ritonavir ve klorokin önerilmektedir. Belirli durumlarda kortikostroidlerden yararlanılabilir. Virüs etanol ve klor içeren dezenfektanlarla inaktive edilebilir. Yakın temasları ve şüpheli maruziyeti olan kişilere, 2019-nCoV ile enfekte hastayla son temas gününden başlayarak 14 günlük gözlem ve izolasyon tavsiye edilmelidir. 2019-nCoV için aşı geliştirme çalışmaları devam etmektedir.

Anahtar kelimeler: 2019-nCoV, SARS-CoV-2, COVID-19, şiddetli akut solunum sendromu

Corresponding Author:

N. Hatipoğlu 0000-0003-2858-0150 naydin9@mynet.com

(C) Telif hakkı Sağlık Bilimleri Üniversitesi Bakırköy Dr. Sadi Konuk Eğitim ve Araştırma Hastanesi'ne aittir. Logos Tıp Yayıncılık tarafindan yayınlanmaktadır. Bu dergide yayınlanan bütün makaleler Creative Commons Atff-GayriTicari 4.0 Uluslararası Lisansı ile lisanslanmıştır.

(C) Copyright Health Sciences University Bakırköy Sadi Konuk Training and Research Hospital. This journal published by Logos Medical Publishing.

Licenced by Creative Commons Attribution-NonCommercial 4.0 International (CC BY-NC 4.0) 


\section{INTRODUCTION}

On 31 December 2019, while people around the world are preparing to see off the "old" year; with the "new" coming year, they were discussing the salary increases that they will receive, the bonus to be released from the lottery, or even though it has a familiar answer, whether December 31 will be a public holiday ${ }^{(1)}$.

At the same date Wuhan Municipal Health Commission in China recently reported on their local websites that a total of 27 local pneumonia cases clustered with findings of fever, breathing difficulties, and chest $x$-ray infiltrations, 7 of which were in serious condition in this South China City of Marine Products ${ }^{(2)}$. It was stated that all cases were thought to have viral pneumonia, and the etiology was not yet known, but the detection of the pathogen and the cause of the infection continued and patients were isolated for treatment.

The city of Wuhan, which has a population of 19 million, also known as "the city of lakes", is a megacity located in Hubei province of China ${ }^{(3)}$. In the central part of the city, there is the Huanan Seafood Market, where wholesale fish and live animals are sold, and it is a crowded shopping mall where food, domestic and a wide variety of wild animals are traded. Regarding this health problem that occurred in late December, the World Health Organization (WHO) reported that the outbreak may be related to exposure there, as some patients were vendors or dealer operators in this market ${ }^{(4)}$. A few days later, on 7 January 2020 Chinese authorities determined that these pneumonia cases were caused by an isolated "new" type of coronavirus ( $\mathrm{nCoV}){ }^{(5)}$. WHO called this newly identified virus the 2019-nCoV (2019 novel coronavirus), as it was first detected in 2019. The virus is also described as Wuhan seafood pneumonia virus, human coronavirus 2019 , severe acute respiratory syndrome coronavirus 2 (SARS-CoV-2) and 2019 coronavirus disease (COVID-19) ${ }^{(6)}$.

\section{ETIOLOGY}

Coronaviruses are enveloped and single-stranded RNA viruses belonging to the Coronaviridae family. Thanks to the surface proteins that appear as an extension to the outside in the form of large crown-like protrusions under electron microscope, they are named as "crown virus" in Latin ${ }^{(7)}$. They can infect humans and a wide variety of animals. The coronavirus causes infections in farm animals, birds, bats, mice and many other wild animals, and each type of virus is unique to the host where it can cause infection. Four groups of coronaviruses (Alphacoronavirus, Betacoronavirus, Gammacoronavirus and Deltacoronavirus) have been identified, and human coronaviruses (HCoVs) belong to the first two types of coronaviruses.

Until $\mathbf{2 0 1 9}$, only six coronaviruses have been identified that are known to cause respiratory diseases in humans. Among these, HCoV-229E, HCoV - OC43, HCoV - NL63 and HKU1 are known as coronaviruses with low pathogenic potential ${ }^{\left({ }^{8}\right)}$. They are responsible for $10-30 \%$ of mild cases with upper respiratory diseases and rarely can cause serious infections in young children and the elderly. Severe acute respiratory syndrome coronavirus (SARS-CoV) and the Middle East respiratory syndrome coronavirus (MERSCoV) are zoonoses ${ }^{(9)}$ that can cause serious and fatal lower respiratory tract infections in human beings and pose an important threat to public health.

2019-nCoV is the seventh member of the coronavirus family that infects humans after MERS-CoV and SARS-CoV. Sequence analysis revealed that 2019$\mathrm{nCoV}$ has a typical coronavirus genome structure and is included in the Betacoronavirus family cluster, which includes SARS and MERS coronaviruses, provided that it is more similar to coronaviruses in bats (10). Within four weeks of the first recognition of the outbreak, the new virus isolated from the airway epithelial cells of patients with pneumonia was shared with WHO using full genome sequencing, polymerase chain reaction and culture methods. With these analyzes, diagnostic tests have been designed to be used in the detection of 2019-nCoV infection in China and globally ${ }^{(11)}$. Since the virus is transmitted to a growing number of people, continuous monitoring of molecular analysis is required as new mutations may emerge

\section{EPIDEMIOLOGY}

The first coronavirus infection in the world, where sudden emergence and global epidemic threat came 
to the agenda, occurred in 2003 with a species that was become known as severe acute respiratory syndrome (SARS). SARS first appeared in China as a new respiratory pathogen in 2002, spread to 29 countries, lasting a total of 9 months, causing infections in 8098 people and 774 deaths. It is thought that SARS$\mathrm{CoV}$ is derived from SARS-CoV-like viruses found in horseshoe bats and probably in musk cats as an intermediate host before the virus "jumped" to the human beings ${ }^{(12)}$.

The coronavirus episode, which concerned the whole world for the second time, started in Saudi Arabia in 2012 and was defined as the Middle East respiratory syndrome (MERS) ${ }^{(13)}$. As of November 2019, 2494 cases diagnosed as MERS and 858 related deaths have been recorded in 27 countries to date ${ }^{(14)}$. The data show that the MERS agent is most likely transmitted from bat coronavirus and camel is the intermediate host. Some types of coronaviruses can also cause epidemics and significant losses in farm animals.

The 2019-nCoV is similar to coronaviruses in SARSCoV (79\%) and MERS-CoV (50\%) and resembling more closely coronaviruses in bats $(96.3 \%$ for BatCoV RaTG13, 88\% for bat-SL-CoVZC45 and bat-SLCoVZXC21). This means that bats may be the original host of this virus. However, it is known that most bat species in Wuhan City were hibernating at the end of December 2019, the first period of the epidemic, and bats were not sold in the Wuhanan seafood market. Therefore, it is estimated that an animal sold in the seafood market in Wuhan may be an intermediate host that facilitated the emergence of this novel virus in humans ${ }^{(15)}$. Based on the analysis of glycoproteins in the capsid of the virus, it has been suggested that the snake may be the most likely animal reservoir as an intermediate host in the transition from bats to humans ${ }^{(16)}$.

Although the relationship of the patients diagnosed at the beginning of the outbreak with the seafood market had been emphasized, any epidemiological connection has not been found in later cases. For this reason, it has been reported that the only source of the virus is not in this market region, but the virus probably entered the market with an intermediate host first and then spread out from there ${ }^{(17)}$.

The news that the 2019-nCoV infection spread out- side of China within three weeks after its first emergence in China began to be heard: Neighboring Thailand, Japan, and Korea were the first countries to report these cases ${ }^{(18,19)}$.

The first appearance of 2019-nCoV infection has been an important issue of curiosity. According to researches, 2019-nCoV probably emerged in Wuhan on November 9, 2019 (95\% confidence interval), September 25, 2019 and December 19, 2019), and Wuhan has been estimated as the main center from where 2019-nCoV outbreak has spreaded in China and elsewhere ${ }^{(20)}$.

One method of determining the extent of infectivity of an infectious agent is known as the basic reproduction number (RO) The R0 value can vary with the reporting rate of the disease. After reporting that the 2019-nCoV infection can pass from person to person (21), RO was calculated between 1.4 and 6.47 in various studies. According to the most comprehensive and up-to-date calculation available today, the doubling rate of the total number of infected people is 1.8 days ${ }^{(22)}$.

Today, the main route of transmission in 2019-nCoV infection is through airborne droplets and direct contact. It has been suggested that fecal-oral transmission may occur because viral particles are detected in the stool samples of pneumonia patients with gastrointestinal symptoms ${ }^{(23)}$.

Early diagnosis, proper isolation and personal protective measures are especially important in the 2019-nCoV infection. Hospital-acquired infection poses a risk to both inpatients and hospital staff. In a clinical series presenting 138 adult patients with 2019-nCoV pneumonia, it was emphasized that $41 \%$ of them, including $29 \%$ of healthcare workers, were suspected of getting the infection by nosocomial transmission ${ }^{(24)}$. People with both evident disease and asymptomatic individuals in incubation period are in critical position for preventing and controlling the outbreak because they have the potential to spread the infection ${ }^{(25)}$.

\section{PATHOGENESIS}

The 2019-nCoV uses angiotensin converting enzyme 2 (ACE2) receptor-binding motif (RBM) as a receptor, 
similar to that of SARS-CoV ${ }^{(26)}$. In other words, 2019nCoV S (spike) -protein and SARS-CoV S-protein share almost the same structure in the RBM domain (27), and the ACE2 receptor region is the gate that the virus uses to enter the cell ${ }^{(28)}$.

ACE2 receptors are found in the lungs mainly in type II alveolar cells. Whether the susceptibility to 2019$\mathrm{nCoV}$ infection is due to individual differences in this region where the virus binds during entry into the cell has been an important subject of research. In a study in which normal lung tissue cells of eight healthy individuals were analyzed, ACE2 expressing the cell ratio was more than five times higher in a single Asian donor than white and African -American donors ${ }^{(29)}$. This means that - although more evidence is needed to reach such a conclusion - the Asian population is probably more susceptible to the 2019nCoV infection.

On the other hand, in another study, any direct genetic evidence was not found to support the presence of ACE2 mutants resistant to coronavirus S-protein binding in different populations. Since the East Asian population has been associated with higher ACE2 expression in tissues, it has been reported that there may be different coronavirus susceptibilities or responses in different populations ${ }^{(30)}$.

China has experienced twice recurring outbreaks of coronavirus (SARS-CoV and its relative SARS-CoV-2) over the past 18 years, suggesting that Asians are more susceptible to coronavirus. ACE2 expression has been studied by Chen et al using transcriptomal data from more than 1000 lung tissue samples within the scope of Cancer Genome Atlas Project, and the following data have been obtained: The expression of ACE2 on the cell surface increases with age, but it is not sex-related. Also, Asians show a similar ACE2 expression to other races. One reason for coronavirus outbreaks occurring over time in China is explained by the diversity of coronaviruses and host animals and the unique Chinese food culture ${ }^{(31)}$

\section{CLINICAL CHARACTERISTICS}

The first case series, consisting of 41 adult patients infected with 2019-nCoV, was published on January
24,2020 . While $66 \%$ of cases had a history of being in the Huanan seafood market. The median age of the patients was 49 years, and there was an underlying disease in $32 \%$ of the patients. While the main diagnosis was pneumonia in all patients, one-third of the patients were followed up in the intensive care units and six of them died. In patients with severe conditions, plasma cytokine concentrations were increased ${ }^{(32)}$.

In another series ${ }^{(33)}$, almost half of 425 cases were found to be adults aged 60 years and older. Infections not as highly frequent as SARS and MERS outbreaks have been identified in healthcare workers. Average incubation time was recorded as 5.2 days ( $95 \%$ confidence interval $[\mathrm{Cl}], 4.1-7.0)$, and the 95th percentile of the distribution was 12.5 days and the mean hospitalization time was 12.5 days

While disease-related ICU hospitalization is required in an average of one fourth of the cases, advanced age and various comorbid conditions are factors that increase mortality ${ }^{(24)}$. Patients may also develop additional infections caused by bacteria or fungi which negatively affect prognosis ${ }^{(34)}$.

In theory, the individual is susceptible to 2019-nCov infection at any age, and the average age is 5-6 decades for reported patients ${ }^{(23,35)}$. Men are more frequently affected, possibly due to higher probability of occupational exposure.

According to reported epidemiological studies, most patients have close contact with a patient with 2019nCoV infection, or a history of travel to Wuhan City or Hubei province in China. The incubation period is usually 3-7 days and can extend up to 14 days.

In 2019-nCoV infection, the symptoms are not specific and are milder than SARS and MERS. The most common symptoms described in adults are high fever, malaise and dry cough; Upper respiratory system symptoms such as a runny nose are rare. Fever may not always be the first sign. Some patients may complain of headache and muscle pain, diarrhea may occur. More than half of the patients may develop shortness of breath within 8 days after the onset of the disease. Acute respiratory distress syndrome (ARDS) may develop, as well as septic shock, 
metabolic acidosis, clotting disorders, and multiple organ failure. Some individuals, and especially children, can pass the infection without fever or symptoms and pose an unnoticed threat in spreading the outbreak

Patients may have decreased total leukocyte, lymphocyte and platelet counts, increase in C-reactive protein and muscle enzymes, and prolonged coagulation tests. D-dimer levels increase in severe disease ${ }^{(36)}$.

It is recommended that all suspect patients are evaluated by chest computed tomography (CT). Chest CT examination shows multiple patchy appearances (lobular and postsegmental consolidation), ground glass changes and thickening of interlobular septa, which are typical for viral pneumonia, and known as cobblestone changes ${ }^{(25)}$.

Radiological disorders in the elderly are more prominent than young patients. In some cases, viral nucleic acid testing may initially be negative. Therefore, lung imaging can be used as a pre-screening method to reveal symptomatic cases, and re-examination of nasopharyngeal swabs or sputum samples is recommended.

The nucleic acid test, performed using the fast-yielding and reliable polymerase chain reaction (PCR) method is employed to determine the disease agent precisely. Viral gene sequencing from nose or throat swabs, as well as sputum, feces or blood samples can be used for definitive identification of the disease agent ${ }^{(36)}$.

\section{THE 2019-nCoV INFECTION IN CHILDREN}

Experience is limited, except for the publication of follow-ups of 28 patients reported in the literature on 2019-nCoV infection in children (37). The main mode of transmission of the infection in children occurs mainly from a sick person who is near them In other words, there is another family member who is sick in the home of a sick child. After transmission of the infection, children are less likely to have an infection with obvious manifestations of the disease than adults. According to the analysis of case series, the clinical features of the disease are milder in children compared to adults, and death has not been report- ed under 10 years of age. Some of the pediatric patients were diagnosed without any complaints using screening tests performed because they contacted the sick people. In symptomatic patients, familiar upper respiratory tract symptoms such as fever, weakness, dry cough, runny nose, and some nausea and vomiting were also observed.

Whole blood cell counts and C-reactive protein values may be usually within normal limits or slightly increased. In the radiological evaluation of the lung, ground glass appearance and bronchial scars may be evident. In the examination of chest CT images of 15 children aged 4-14 years diagnosed with 2019-nCoV infection, 9 patients had pulmonary signs of inflammation, usually in the form of nodular ground-glass opacities. In addition, clinical symptoms are not specific ${ }^{(38)}$.

The clinical course usually takes 1-2 weeks. Although progression to pneumonia and serious cases are rarely seen, ARDS should be kept in mind in children with other serious coronavirus infections such as MERS.

Pregnancy is generally a period of increased sensitivity to viral infections. Our knowledge about coronavirus infections that occur during pregnancy is limited. The risks that pregnant women have in the 2019nCoV outbreak have not been determined yet. Although greater number of pregnant women have not been affected in both the SARS pandemic and MERS infection, disease -related mortality rates in pregnant women were as high as $25 \%$ and $27 \%$, respectively ${ }^{(39)}$. Hypoxemia due to severe infection in pregnant women can lead to intrauterine asphyxia and preterm labor. Fortunately, as of 04.03.2020, placentally transmitted fetal infection with SARS or MERS has not been reported yet. However, it should be taken into consideration that pregnant women may have a serious risk of developing infections during the 2019-nCoV outbreak ${ }^{(40)}$. Although a 30-hourold newborn baby was shown to be infected with 2019-nCoV viruses which were detected in both mother and caregiver, placental transmission of the disease in newborn was not proven ${ }^{(41)}$. According to available data, it has not been clarified whether it is transmitted from mother to baby during pregnancy or with breast milk ${ }^{(36)}$. 
The COVID-19 (2019-nCoV Disease) Guide, prepared by the TR Scientific Committee Study of the Ministry of Health General Directorate of Public Health and last updated on March 11, 2020 is a source of information concerning case definition and management, contact tracking, infection control and isolation, patient care and treatment. It also includes information about the requirements requested from individuals who will travel to the countries where this infection was seen ${ }^{(42)}$.

\section{TREATMENT}

Four principles are important in patient management: "early recognition", "early isolation", "early diagnosis" and "early treatment" (36).

Patients with mild complaints should remain isolated in their homes. As general treatment principles, supportive treatments such as providing bed rest, adequate calorie and fluid intake and meeting the need for oxygen should be implemented, and followed up closely. In cases where secondary bacterial infection cannot be excluded, antibiotics can be added to the treatment.

An effective antiviral treatment is not yet available; however, in severe cases, interferon- $\alpha$ nebulization and although its efficacy has not been proven, oral

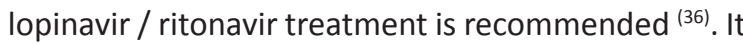
is emphasized that antiviral therapy is useful when started in an early stage of the disease ${ }^{(25)}$.

Interferon- $\alpha$ is a broad spectrum antiviral drug used in the treatment of HBV. Lopinavir and ritonavir are protease inhibitors used to treat human immunodeficiency virus (HIV) infection and have in vitro anti coronavirus activity.

Remdesivir is an effective adenosine analog antiviral agent for various RNA viruses (including SARSCoV / MERS-CoV). In MERS-CoV-infected mice remdesvir has been shown to suppress the virus and improve lung tissue damage. Phase III clinical trials have been conducted with the same drug for the treatment of Ebola virus infection ${ }^{(43)}$. As a recent data, the drug has been shown to inhibit virus infection in a 2019-nCoV- sensitive human cell line (human liver cancer cells). In addition to being an antimalarial drug, chloroquine has immunoregulatory and antiviral activity. The combined use of both drugs was found to be effective in vitro against 2019-nCoV infection ${ }^{(44)}$. It should be emphasized that developments regarding the treatment of the disease are a very dynamic process.

Although not a routine practice, corticosteroids can be used in certain situations: such as ARDS, encephalitis, toxicosis, hemophagocytosis, septic shock, and prominent wheezing. Intravascular immune globulin is also used in the treatments recommended for the severe clinical entities. For respiratory support, ventilation technique and hemo (dia) filtration / plasma exchange can be applied.

Traditional Chinese medicine, arbidol and mesenchymal stem cell transplant applications are studies to be performed in near future in which some of the pediatric patients are planned to be included ${ }^{(45)}$.

\section{PREVENTION}

The 2019-nCoV can be inactivated by heating for 30 minutes at $56^{\circ} \mathrm{C}$ and with disinfectants containing $75 \%$ ethanol and chlorine, while chlorhexidine is partly effective.

People with close contact and suspicious exposure should be advised to observe the 14-day social isolation. Period starting from the last day of the contact with 2019-nCoV-infected patients or suspected environmental exposure.

Special means of transportation should be used to transfer infected patients. Strict protection for transport personnel and disinfection for the vehicle is vital.

Medical personnel should act in accordance with appropriate personal protection, hand hygiene, ward management, environmental ventilation, object surface cleaning and disinfection, medical waste management and other hospital infection control studies based on the standard prevention protocol to minimize development of nosocomial infection.

Vaccine development studies for 2019-nCoV are ongoing. Approximately 15 potential vaccine candi- 
dates are being studied by applying various technologies such as messenger RNA, DNA-based, nanoparticle, synthetic and modified virus-like particles ${ }^{(45)}$.

It is within the capacity of modern medicine to carry out a systematic arrangement and preparation against the ongoing epidemic in every aspect due to the 2019-nCoV, the most current world-threatening viral infection of the twenty-first century.

\section{Funding: None.}

\section{REFERENCES}

1. https://www.hurriyet.com.tr/gundem/bugun-okullar-tatilmi-31-aralik-yarim-gun-mu-41409339

2. Report of clustering pneumonia of unknown etiology in Wuhan City. Wuhan Municipal Health Commission, 2019. http://wjw. wuhan.gov.cn/front/web/showDetail/2019123108989).

3. https://cinhaber.net/guncel/sunger-sehir-wuhan-h1728. html).

4. https://www.who.int/csr/don/05-january-2020-pneumoniaof-unkown-cause-china/en/

5. http://www.xinhuanet.com/english/2020-01/09/ c_138690570.htm

6. https://www.ncbi.nlm.nih.gov/Taxonomy/Browser/wwwtax. cgi?id=2697049

7. Virology: Coronaviruses. Nature 1968 Nov 16;220:650 https://doi.org/10.1038/220650b0

8. Su S, Wong G, Shi W, et al. Epidemiology, Genetic Recombination, and Pathogenesis of Coronaviruses. Trends Microbiol. 2016;24(6):490-502. https://doi.org/10.1016/j.tim.2016.03.003

9. Cui J, Li F, Shi ZL. Origin and evolution of pathogenic coronaviruses. Nat Rev Microbiol. 2019 Mar;17(3):181-192. https://doi.org/10.1038/s41579-018-0118-9

10. Chen Y, Liu Q, Guo D. Emerging coronaviruses: Genome structure, replication, and pathogenesis. J Med Virol. 2020 Apr;92(4):418-423. https://doi.org/10.1002/jmv.25681

11. Zhu N, Zhang D, Wang W, et al; China Novel Coronavirus Investigating and Research Team. A Novel Coronavirus from Patients with Pneumonia in China, 2019. N Engl J Med. 2020 Feb 20;382(8):727-733. https://doi.org/10.1056/NEJMoa2001017

12. Hui DSC, Zumla A. Severe Acute Respiratory Syndrome: Historical, Epidemiologic, and Clinical Features. Infect Dis Clin North Am. 2019 Dec;33(4):869-889. https://doi.org/10.1016/j.idc.2019.07.001

13. Azhar El, Hui DSC, Memish ZA, Drosten C, Zumla A. The Middle East Respiratory Syndrome (MERS). Infect Dis Clin North Am. 2019 Dec;33(4):891-905. https://doi.org/10.1016/j.idc.2019.08.001

14. https://www.who.int/emergencies/mers-cov/en/.

15. Lu R, Zhao X, Li J, et al. Genomic characterisation and epidemiology of 2019 novel coronavirus: implications for virus origins and receptor binding. Lancet. 2020Feb 22;395(10224):565574. https://doi.org/10.1016/S0140-6736(20)30251-8

16. Ji W, Wang W, Zhao X, Zai J, Li X. Cross-species transmission of the newly identified coronavirus 2019-nCoV. J Med Virol. 2020 Apr;92(4):433-440. https://doi.org/10.1002/jmv.25682

17. Cohen J. Wuhan seafood market may not be source of novel virus spreading globally. https://www.sciencemag.org/ news/2020/01/wuhan-seafood-market-may-not-be-sourcenovel-virus-spreading-globally. Erişim: 02 Mart 2020. https://doi.org/10.1126/science.abb0611

18. World Health Organization Novel Coronavirus (2019-nCoV) Situation Report-1: 21 January 2020

19. https://www.who.int/emergencies/diseases/novel-coronavirus-2019/situation-reports

20. Li X, Zai J, Wang X, Li Y. Potential of large "first generation" human-to-human transmission of 2019-nCoV. J Med Virol. 2020 Apr;92(4):448-454 https://doi.org/10.1002/jmv.25693

21. Chan JF, Yuan S, Kok KH, et al. A familial cluster of pneumonia associated with the 2019 novel coronavirus indicating personto-person transmission: a study of a family cluster. Lancet. 2020 Feb 15;395(10223):514-23. https://doi.org/10.1016/S0140-6736(20)30154-9

22. Cheng ZJ, Shan J. 2019 Novel coronavirus: where we are and what we know. Infection. 2020 Feb 18 https://doi.org/10.20944/preprints202001.0381.v1

23. Han Q, Lin Q, Jin S, You L. Recent insights into 2019-nCoV: a brief but comprehensive review. J Infect. 2020 Feb 25.

24. Wang D, Hu B, Hu C, et al. Clinical Characteristics of 138 Hospitalized Patients With 2019 Novel Coronavirus-Infected Pneumonia in Wuhan, China. JAMA. 2020 Feb 7. https://doi.org/10.1001/jama.2020.1585

25. Jin $\mathrm{YH}$, Cai L, Cheng ZS, et al. A rapid advice guideline for the diagnosis and treatment of 2019 novel coronavirus (2019$\mathrm{nCoV}$ ) infected pneumonia (standard version). Mil Med Res. 2020 Feb 6;7(1):4

26. Wan Y, Shang J, Graham R, Baric RS, Li F. Receptor recognition by novelcoronavirus from Wuhan: An analysis based on decade-long structural studies of SARS. J Virol. 2020 Jan 29. https://doi.org/10.1128/JVI.00127-20

27. Xu X, Chen P, Wang J, Feng J, Zhou H, Li X, Zhong W, Hao P. Evolution of the novel coronavirus from the ongoing Wuhan outbreak and modeling of its spike protein for risk of human transmission. Sci China Life Sci. 2020 Jan 21. https://doi.org/10.1007/s11427-020-1637-5

28. Zhou $\mathrm{P}$, Yang XL, Wang XG, et al. A pneumonia outbreak associated with a new coronavirus of probable bat origin. Nature. 2020 Feb 3.

29. Zhao Y, Zhao Z, Wang Y, Zhou Y, Ma Y, Zuo W. Single-cell RNA expression profiling of ACE2, the putative receptor of Wuhan 2019-nCoV. bioRxiv preprint 2020. 01.26.919985; doi: https:// doi.org/10.1101/2020.01.26.919985. https://doi.org/10.1101/2020.01.26.919985

30. Cao Y, Li L, Feng Z, et al. Comparative genetic analysis of the novel coronavirus (2019-nCoV/SARS-CoV-2) receptor ACE2 in different populations. Cell Discov 6, 11 (2020). https://doi. org/10.1038/s41421-020-0147-1 https://doi.org/10.1038/s41421-020-0147-1

31. Chen Y, Shan K, Qian, W. Asians and Other Races Express Similar Levels of and Share the Same Genetic Polymorphisms of the SARS-CoV-2 Cell-Entry Receptor. Preprints 2020, 2020020258 (doi: 10.20944/preprints202002.0258.v1) https://doi.org/10.20944/preprints202002.0258.v1

32. Huang $C$, Wang $Y$, Li $X$, et al. Clinical features of patients infected with 2019 novel coronavirus in Wuhan, China. Lancet. 2020 Feb 15;395(10223):497-506. https://doi.org/10.1016/S0140-6736(20)30183-5

33. Li Q, Guan X, Wu P, et al. Early Transmission Dynamics in Wuhan, China, of Novel Coronavirus-Infected Pneumonia. N Engl J Med. 2020 Jan 29.

34. Chen N, Zhou M, Dong X, et al. Epidemiological and clinical characteristics of 99 cases of 2019 novel coronavirus pneumonia in Wuhan, China: a descriptive study. Lancet. 2020 Feb 15;395(10223):507-513. https://doi.org/10.1016/S0140-6736(20)30211-7

35. She J, Jiang J, Ye L, Hu L, Bai C, Song Y. 2019 novel coronavirus of pneumonia in Wuhan, China: emerging attack and management strategies. Clin Transl Med. 2020 Feb 20;9(1):19. 
https://doi.org/10.1186/s40169-020-00271-z

36. Chen ZM, Fu JF, Shu Q, et al. Diagnosis and treatment recommendations for pediatric respiratory infection caused by the 2019 novel coronavirus. World J Pediatr. 2020 Feb 5. https://doi.org/10.1007/s12519-020-00345-5

37. Shen KL, Yang YH. Diagnosis and treatment of 2019 novel coronavirus infection in children: a pressing issue. World J Pediatr. 2020 Feb 5. https://doi.org/10.1007/s12519-020-00344-6

38. Feng K, Yun YX, Wang XF, Yang GD, Zheng YJ, Lin CM, Wang LF. [Analysis of CT features of 15 Children with 2019 novel coronavirus infection]. Zhonghua Er Ke Za Zhi. 2020 Feb 16;58(0):E007.

39. Favre G, Pomar L, Musso D, Baud D. 2019-nCoV epidemic: what about pregnancies? Lancet. 2020 Feb 22;395(10224): e40.

https://doi.org/10.1016/S0140-6736(20)30311-1

40. Schwartz DA, Graham AL. Potential Maternal and Infant Outcomes from (Wuhan) Coronavirus 2019-nCoV Infecting
Pregnant Women: Lessons from SARS, MERS, and Other Human Coronavirus Infections. Viruses. 2020 Feb 10;12(2). https://doi.org/10.3390/v12020194

41. Science Media Centre. Expert Reaction to Newborn Baby Testing Positive for Coronavirus in Wuhan. https://www.sciencemediacentre.org/expert-reaction-to-newborn-baby-testing-positive-for-coronavirus-in-wuhan/ (erişim:04.03.2020).

42. https://hsgm.saglik.gov.tr/depo/covid19/rehberler/COVID19 Rehberi.pdf

43. Lu H. Drug treatment options for the 2019-new coronavirus (2019-nCoV). Biosci Trends. 2020 Jan 28. https://doi.org/10.5582/bst.2020.01020

44. Wang M, Cao R, Zhang,et al. Remdesivir and chloroquine effectively inhibit the recently emerged novel coronavirus (2019-nCoV) in vitro. Cell Res. 2020 Feb 4. https://doi.org/10.1038/s41422-020-0282-0

45. Pang J, Wang MX, Ang IYH, et al. Potential Rapid Diagnostics, Vaccine and Therapeutics for 2019 Novel Coronavirus (2019nCoV): A Systematic Review. J Clin Med. 2020 Feb 26;9(3) 